\title{
Public water and waste management in Nigeria: legal framework, obstacles and challenges.
}

\author{
By Lohya Ibrahim LAKAI. LLB, BL*
}

\begin{abstract}
This articled examines public water and waste management in Nigeria: Legal framework, obstacles and challenges. Public water and waste management has emerged as one of the greatest challenges facing environmental protection in Nigeria. The question of Legal framework in relation to public water and waste management is characterized by inefficient workforce, corruption, insufficient policies and poor enforcement of same. It is only proper, therefore, that certain legal measures be taken at the national level to control the situation and bring effective solution. Therefore, if there is to be sustainable development in waste management in Nigeria, the availability of land (for landfill), human resources, plant and equipment and other tools including capital must be readily available. But these would have great limitation without functional legal structure.
\end{abstract}

\section{INTRODUCTION}

There was a radical reappraisal towards the end of 1980s which raised series of concern over resource availability and use in Nigeria. The same move also gave prominence to the environmental consequences of resource misuse and the correlation between poverty on the one hand, and the environment on the other hand. These have a way of interfacing on the subject of water and waste management while creating a new approach to environment and legal issues. The concept of waste management includes the activities and actions required to manage waste from its inception to its final disposal. This includes the collection, transport, treatment and disposal, together with monitoring and regulation of the waste management process (specifically, in such a way as to render it harmless to human and animal life, the ecology and the environment generally).

Adequate supply of safe and sanitized fresh water is an inevitable factor for human and economic development. This is entirely inseparable from the ecology and the entire environment. Several decades ago, the issues relating to water waste management were not given significant priority partly because Nigeria's population was relatively small and the

* Mrs Lohya Ibrahim Lakai is a Principal State Counsel in the Plateau State Ministry of Justice, Jos, Nigeria. She holds a Bachelor of Law Degree (LLB) from Ahmadu Bello University Zaria, Nigeria and a Bachelor of Law (BL\} from the Nigerian Law School, Lagos Campus. She was called to the Nigerian Bar in the year 2008. 
amount of land available for assimilation of wastes was large. ${ }^{1}$ Waste generation is a natural phenomenon of life in human existence. As consumption and industrial activities increases, so would waste. Wastes are generated in all economies of the world, be it developed or developing economies and these wastes can be in diverse forms. These wastes generated in the course of human development are handled differently. Domestic Waste Management has become an area of major concern in Nigeria today. The Environmental problems arising from indiscriminate dumping of refuse are actually begging for some form of attention, control and management. To deal with domestic waste, there is a need for proper waste management regime to combat the harmful consequences of unguided waste and to ensure a clean and healthy environment for all Nigerians. ${ }^{2}$

It has clearly been established that, pollution of domestic water is an ongoing problem in most Nigerian communities, especially the government-ignored villages. The tragedy is seriously crippling human development, proper identification of preventive and control measures would be very useful. The key ways forward in this respect are the proper education of local people on the importance of water sanitation and good waste disposal methods, establishment of water treatment plants and good regulatory strategies. Adequate budgetary funding is therefore necessary. ${ }^{3}$

Currently, the increasing and diversified wastes resulting from the rapid economic growth, citing of production companies, mining activities (especially in the Niger-Delta region) and overpopulation, especially in certain urban areas such as Lagos, Abuja, Port- Harcourt, Kano and certain state capitals, have made public water and management of wastes one of the major concerns of Nigeria as a whole. According to findings, Lagos Lagoon alone is estimated to absorb 10,000 M3 of industrial effluent daily. ${ }^{4}$ Another study on Nigeria's waste posit that the waste density ranged from 280 to $370 \mathrm{~kg} / \mathrm{m} 3$ and the waste generation rates ranged from 0.44 to $0.66 \mathrm{~kg} /$ capita/day. $^{5}$

\section{A. Public water}

The significance of water to human and other biological systems cannot be over emphasized, and there are numerous scientific and economic facts that, water shortage or its pollution can cause severe decrease in productivity and deaths of living species (Garba et al.,

1 Garba, Z. N., Leke, L., Almustapha, M. N., Adam, I. K. Domestic Water Pollution among Local Communities in Nigeria: Causes and Consequences.

2 Akpoghome, Theresa U. Managing Domestic Waste in Nigeria: Legal Framework, Problems and Solutions. International Journal of Environment, Ecology, Family and Urban Studies (IJEEFUS) ISSN(P): 2250-0065; ISSN(E): 2321-0109, Vol. 4, Issue 6, Dec 2014, 7-28

3 Garba, Z. N., Leke, L., Almustapha, M. N., Adam, I. K. Domestic Water Pollution among Local Communities in Nigeria: Causes and Consequences.

4 Adewole, A. Taiwo Waste management towards sustainable development in Nigeria: A case study of Lagos state.

5 Ogwueleka, T. Ch., Municipal solid waste characteristics and management in Nigeria. Iran. J. Environ. Health. Sci. Eng., 2009, Vol. 6, No. 3, pp. 173-180173. 
2008; Garba et al., 2010). In 2010, the UN General Assembly explicitly recognized the human right to water and sanitation. Safe and readily available water is important for public health, whether it is used for drinking, domestic use, food production or recreational purposes. ${ }^{6}$ Everyone has the right to sufficient, continues, safe, acceptable, physically accessible, and affordable water for personal and domestic use. However, in Nigeria, water related diseases had been interfering with basic human development. ${ }^{7}$

Public water, also described as community water, is a system of regulation referring to certain utilities (specifically, water) and any such interface: the supply, the duration or availability and the benefactor - the community in question (in this case - Nigerian communities). A public water system provides water for human consumption through pipes or other constructed conveyances beyond those who are connected to the grid - in Nigeria, neighbours come to fetch from taps of those who are connected, and the community fetching points. It is one of the most crucial considering the level of such community's dependability to this one source of supply. Contaminated water, which is usually not so at the source, can transmit diseases such as cholera, typhoid, diarrhea, dysentery and even polio. These are diseases very peculiar to Nigeria. But because the initial sources of water are usually considered pure, the contamination of water is predominantly related to waste and, invariably, waste management.

Water pollution occurs when unwanted materials with potentials to threaten human and other natural systems find their ways into rivers, lakes, wells, streams, boreholes or even reserved fresh water in homes and industries. The pollutants are usually pathogens, silt and suspended solid particles such as soils, sewage materials, disposed foods, cosmetics, automobile emissions, construction debris and eroded banks from rivers and other waterways. Some of these pollutants are decomposed by the action of micro-organisms through oxidation and other processes.

According World Health Organization, 785 million people lack even a basic drinkingwater service, including 144 million people who are dependent on surface water. It further states that, globally, at least 2 billion people use a drinking water source contaminated with faeces. Such contaminated drinking water is estimated to cause 485,000 diarrhoeal deaths each year. ${ }^{8}$ United Nations corroborates this by adding that 2.2 billion people lack access to safely managed drinking water services and 4.2 billion people lack safely managed sanitation services. The benefits of having access to an improved deinking water source can only

6 World Health Organization, Drinking Water, 14 June 2019, https://www.who.int./news-room/fact-sh eets/detail/drinking-water.

7 Food and Agricultural Organisation (FAO, 2007): Coping with water scarcity, 2007 World Water Day, 22nd March, 2007. Available on 1270172010 from: http://www.fao.org/nr/water7docs/wwd0 7 brochure.pdf.

8 World Health Organization, Drinking Water, 14 June 2019, https://www.who.int./news-room/fact sheets/detail/drinking-water. 
be realized when there is also access to improved sanitation and adherence to good hygiene practices. ${ }^{9}$ This puts the concept of waste management in perspective.

\section{B. Appraisal of Waste management in Nigeria}

It is a common sight in Nigeria today to see heaps/festering waste dumps in our urban and commercial cities. This sight is quite unwholesome and very nauseating. This is an indication that we have a major problem with domestic waste management. ${ }^{10}$ Defining waste has its origins in the management of unwanted and discarded material, where waste historically was disposed without consideration for the resultant environmental consequences or the reuse or recycling potential. The management of waste, both locally and internationally, has been incorporated into environmental legislation to protect both the environment and human health from any adverse effects of waste disposal. ${ }^{11}$

That being said, waste management is one of the striking environmental challenges of Nigeria, especially in rural areas. With its population that now exceeds 170 million, it makes Nigeria amongst the most significant producers of solid waste all around the continent. Every year, there are about 32 million tons generated and only 20 to 30 percent of them are collected. This is a fact, despite the regulations and policies on solid waste. ${ }^{12}$ There are more plastics, more papers, more e-wastes, more abandoned projects and poorly executed road networks (without drainages). In Nigeria, enclosed drains for the disposal of domestic waste water, and rain storms are limited. In areas where there are no drains, domestic waste water stinks in gutters around dwelling places.

The federal environmental protection act (1988) does not define "waste", however Waste as the term implies is any solid, liquid or gaseous substances or materials which being a scrap or being super flows, refuse or reject, is disposed of, or required to be disposed as unwanted, this is Environmental law, the term assumes it's ordinary literal meaning unlike in the real property Law, When" waste" is used as a term of art, having meaning completely different from its ordinary meaning.

In Nigeria, managing waste disposal has become a major concern. Several attempts by government has not yielded meaningful result. One of the few statues in Nigeria, which attempts to define waste is the Lagos State Environmental Edicts 1985, there in Section 32, waste is defined as follows:

9 United Nations, Water, Sanitation and Hygience, https://www.unwater.org/water-facts/water-sanita tion-and-hygiene/.

10 Akpoghome, Theresa U. Managing Domestic Waste in Nigeria: Legal Framework, Problems and Solutions. International Journal of Environment, Ecology, Family and Urban Studies (IJEEFUS) ISSN(P): 2250-0065; ISSN(E): 2321-0109, Vol. 4, Issue 6, Dec 2014, 7-28

11 Oelofse, S.H.H., and Godfrey, L. Defining waste in South Africa: Moving beyond the age of 'waste'.

12 TVC News Nigeria, Waste management, an environmental challenge in Nigeria, July 26, 2019. 
Waste includes:

i.) Waste of all description.

ii.) Any substance, which constitutes scrap materials or an effluent or other unwanted surplus substance arising from the application of any process. ${ }^{13}$

The United Kingdom's Environmental Protection Act 1990, re-enacting an earlier U.K statue, took this statutory definition a step further in section 75(2), it defines waste in the following terms to include:

i.) Any substance which' constitutes a scrap material or an effluent or other unwanted surplus substance arising from the application of any process and

ii.) Any substance or article, which requires to be disposed of as being broken, worn out, contaminated or otherwise spoiled.

The goal of waste management is to minimize the negative effects of rubbish on the environment and humanity, and find ways to recycle the materials that are a potential havoc to the planet in general. However, there are few deliberate efforts to manage waste in Nigeria such as that from WeCyclers being led by Wale Adebiyi. It is founded on a bottom-up approach, pyramid scheme based, for helping low income community to get value for their waste. Households are approached, then told the value of their waste. They are subsequently given incentives for availing their wastes which are then given to mega recycling companies (there are about four hubs in Lagos for this purpose). ${ }^{14}$

\section{Integrating the principles of seven Rs}

Certain principles have been suggested as part of efforts for effective waste management.

The principle of Rethinking: Citizens are invited to rethink their habits in regards to needs or basic necessities/requirement. For instance, one would ask: "Do I really need this now?

The principle of Refusing: Refuse anything that would harm the environment. Countries like China, Bangladesh and even Somalia have refused the use of plastic bag carriers by imposing a ban on it.

The principle of Regulating: Nigerians are in the habit of throwing away waste anywhere. Many industries release or dump their waste into water bodies or open spaces.

The principle of Reducing: This principle focuses on reduction in waste generation. This can be done by repairing, and sharing.

The principle of Reuse: This means using something again more than one time and thereby, reducing the generation of waste. Here, we ought to think of the ways to use a pro-

13 Adewole, A. Taiwo Waste management towards sustainable development in Nigeria: A case study of Lagos state.

14 Wale Adebiyi, Recycling in Nigeria by WeCyclers. Wazobia Max TV. 
duct to its fullest. However, to promote waste re-use, there is a need for a clear definition of waste, and perhaps more importantly, clarity on when something ceases to be waste.

The principle of Recycle: this is the reprocessing of unwanted materials into new, useful products or form. Think of how we can make new products out of the old ones.

The principle of Research: as intelligent beings we ought to research and develop new innovative ways to reuse the unwanted materials and reduce the generation of same. ${ }^{15}$

These, notwithstanding, Nigeria's quest towards achieving the sustainable development goals (SDGs) by 2030 would be an exercise in futility if the country refuses to implement strategies, practices and processes to manage its rising waste level. To put this paper in context, however, waste management is the umbrella term for the actions necessary to handle rubbish from its first collection to its disposal. It also includes the legal and regulatory frameworks that are used to deal with issues relating to managing wastes. ${ }^{16}$ It sets the tone for the next segment of this paper. This paper focuses on the legal framework, obstacles and challenges. Because, to control the activities leading to rising levels of waste, we need Rules and Regulations.

\section{Legislation and legal provisions in Nigeria}

A number of laws have been put in place at the Federal and State levels in Nigeria for the purpose of waste management. Apart from the federal and state laws, there is also the Constitutional provision. The Federal Government of Nigeria has promulgated various laws and regulations to safeguard the environment. These include Federal Environmental Protection Agency Act of 1988. The Federal Ministry of Environment administers and enforces environmental laws in Nigeria. It took over this function in 1999 from the Federal Environmental Protection Agency (FEPA), which was created under the FEPA Act. Pursuant to the FEPA Act, each state and local government in the country set up its own environmental protection body for the protection and improvement of the environment within its jurisdiction. ${ }^{17}$

The F.E.P.A Act was the first major environmental legislation passed by the nation. The Agency was established by section 1 of the Federal Environmental Protection Agency Act with the ability to sue and be sued in its corporate name. ${ }^{18}$ The agency was vested with the responsibility for the protection of the environment in Nigeria. However, the Act has been repealed and replaced by the NESREA Act but deserves to be mentioned.

15 What is waste Management? Reduce Reuse Recycle. Environmental Science. Letsute. Published on March 4, 2019. https://youtu.be/K6ppCC3lboU.

16 Understanding the Basics of Waste management, https://skipthetip.com/understanding-basic-waste -management/.

17 Ogwueleka, T. Ch., Municipal solid waste characteristics and management in Nigeria. Iran. J. Environ. Health. Sci. Eng., 2009, Vol. 6, No. 3, pp. 173-180 173.

18 Cap 131 Laws of the Federation of Nigeria, 1990 [formerly Decree No. 58, 1988] Cap. F10 LFN 2004. 
The Agency was established by section 1 of the NESREA Act, to be the enforcement agency for environmental standards, regulations, rules, laws, policies and guidelines. ${ }^{19}$ It is a body corporate with perpetual succession and a common seal; and may sue and be sued in its corporate name. ${ }^{20}$ The functions and powers of the Agency are as listed in sections 7 and 8 of the Act. In exercise of the powers conferred on the Minister of Environment by section 34 to make Regulations, one was made for environmental sanitation and waste control ${ }^{21}$ and the commencement date was $30^{\text {th }}$ September, 2009. Section 3 of Regulation provides that:

No person is to discard, throw or drop any litter or any similar refuse anywhere except in designated litter bins, no owner, operator, occupant or person in care, management or control of premises is to allow the release of litter into the environment; no occupant or passenger of any vehicle is to throw or drop any litter into the streets, roads, highways, public spaces and other undesignated places. ${ }^{22}$

However, the Nigerian Constitution is the beacon for the protection of the rights of the citizens. Section 20 provides: States shall protect and improve the environment and safeguard the water, air, Land, forest and wildlife. ${ }^{23}$ Regrettably, this provision of the people's right to a protected environment is made an integral part of the fundamental objectives and directive principles of state policy covered in chapter 2 of the Constitution. It is worthy to note that section 33 of the 1999 Constitution as amended can be used to protect the right of the citizens to a clean environment. According to Alfred O. Okukpon22 he posits that Our environment is anchored on the fact that a right to life implies a right to live in an environment which is devoid of any injurious degradation.

The Legal framework or even the definition of what constitutes waste itself can often be problematic and dependent on factors other than the composition or possible after-use of certain materials. Critical issues bother on:

i. Cleaner production (prevention and minimization),

ii. Recycling (re-use, recovery/reclamation, composting)

iii. Treatment (physical, chemical, biological)

iv. Disposal (landfill)

Section 4 of the $\mathrm{Act}^{24}$ sets out the functions of the agency as follows:

The Agency shall, subject to this Act, have responsibility for the protection and development of the environment and biodiversity conservation and sustainable development of

19 Section 1 (2) (a) NESREA Act, 2007.

20 Section 1 (2) (b) (c) NESREA Act, 2007.

21 National Environmental (Sanitation and Waste Control) Regulations, 2009.

22 Regulations 3 (1) (2) (3), National Environmental (Sanitation and Waste Control) Regulations, 2009.

231999 Constitution of the Federal Republic of Nigeria as amended.

24 The NESREA Act. 
the nation's natural resources in general and environmental technology, including initiation of policy in relation to environmental research and technology; and without prejudice to the generality of the foregoing, it shall be the duty of the agency to:

- Advise the Federal Government on national environmental policies and priorities and on scientific and technological activities affecting the environment;

- Prepare periodic master plans for the development of environmental science and technology and advise the Federal Military Government on the financial requirements for the implementation of such plan;

- Promote cooperation in environmental science and technology with similar bodies in other countries and with international bodies;

- Co- operate with Federal and State ministries and local government councils, statutory bodies and research agencies on matters and facilities relating to environmental protection; and

- Carryout such other activities as are necessary or expedient for the full discharge of the functions of the Agency under this Act.

The European Court of Justice, for instance, has stated that the term 'waste', in European Union legislation, implies 'discard'. Within the European Union, many of the cases dealing with, or testing the definition of waste arise out of criminal prosecutions for violations of waste management regulations, where criminal liability depends on whether the substance or material concerned falls within the legal definition of waste. As a result, the UK government has acknowledged the need for a full debate on the interpretation of the definition of waste, to provide industry and competent authorities with increased clarity in this regard. The European Community's Sixth Environment Action Programme calls for 'clarification of the distinction between waste and non-waste' and this issue seems set to remain topical for some time to come. ${ }^{25}$

Industry and government need to have the same understanding as to what is waste and what is a by-product (material with the potential for re-use, whether a re-use market currently exists or not).

The definition of waste should allow for responsible waste recovery, recycling and reuse without creating a threat of criminal liability in terms of waste legislation, while at the same time, not ignoring the potential environmental and human health impacts associated with these activities. European case law gives a legal resolve on when waste is no longer considered waste. If material can be re-used without further processing and if there is financial advantage to be gained from the re-use, the substance in question should not be regarded as waste, but as a legitimate product. The reasoning applicable to byproducts should be confined to situations in which the re-use of the goods, materials or raw materials is not a

25 Staker C. (2005). The definition of 'waste' in the Waste Framework Directive. Eur. Curr. Law, March 2005. 
mere possibility but a certainty. ${ }^{26}$ The Environmental Public Health Act (EPHA) ${ }^{27}$ defines waste as 'any substance which constitutes a scrap material or an effluent or other unwanted surplus substance arising from the application of any process; and any substance or article which requires to be disposed of as being broken, worn out, contaminated or otherwise spoiled, and anything which is discarded or otherwise dealt with as if it were waste shall be presumed to be waste unless the contrary is proved.' The definition of disposal facility, similar to South African legislation, also includes a recycling facility, subjecting recycling facilities to the same controls as disposal facilities. This definition of waste therefore assumes just about everything to be waste unless the producer or generator can provide proof that it is not. Here, on the continent, in South Africa, there is currently more than one legal definition of waste. This not only complicates the classification of material as waste, but also creates confusion amongst industry and government dealing with waste management issues. Firstly, this hinders the successful implementation of the waste hierarchy that aims at diverting waste away from landfill by promoting sustainable waste recycling and re-use. ${ }^{28}$ Secondly, it gives a clue into the complexities surrounding the establishment of a functional Legal frame work. In spite, it is necessary to keep a control on our activities.

\section{E. Obstacles and Challenges}

Corruption is prominent in every discourse about Nigeria. Recently, there were series of allegations on corruption within the Niger Delta Development Commission (NDDC). The region in question suffers the most ranging from pipe spillage to other forms of waste-related damages. Sadly, and based on allegations, those officials meant to facilitate the management of this region are being invited to defend themselves against corruption. In some cases, closed dumpsites are still being used illegally among several other illegal dumpsites that adorn our towns and cities. Bodies for the responsibility of supervision are more interested in making money from defaulters than discharge their duties devoid of corrupt practices. Most industries have no pollution abatement programme for their effluent.

Lack of efficient law-enforcement instrument has significantly resulted to waste disposal into fresh waterways by sellers of different food and cosmetics in our markets. This could be fully addressed by improving awareness and ensuring total compliance with the applied laws and practices. Prosecution of defaulters would be very important here. The successful implementation of the waste largely depends on its translation into policy, strategy and legislation. However, one of the main obstacles to successful implementation ap-

26 Bainbridge T. (2006). Secondary materials: Will new rules make a new beginning for the end-ofwaste? Conference proceedings of theWaste2006 conference held in Statford-upon-Avon, Warwickshire, U.K.

27 Singapore Ministry of Environment (2002). Environmental Public Health Act, Act 14 of 1987; 2002 revised edition. Available online: http://statutes. agc.gov.sg.

28 Oelofse, S.H.H., and Godfrey, L. Defining waste in South Africa: Moving beyond the age of 'waste'. South African Journal of Science 104, July/August 2008. 
pears to be the legal interpretation by both government and industry, and the establishment and implementation of functional waste-related policies.

Therefore, if there is to be sustainable development in waste management in Nigeria, the availability of land (for landfill), human resources, plant and equipment and other tools including capital must be readily available. But these would have great limitation without functional legal structure. This is crucial because we need to protect future for the next generation by cleaning up our environment of all types of waste, taking into consideration both physical and population development of the country.

\section{F. Conclusion}

There are lots of danger facing humanity which bothers on the issues of public water and waste management. It is only proper, therefore, that certain legal measures be taken at the national level to control the situation and bring effective solution. Climate change, increasing water scarcity, population growth, demographic changes and urbanization already pose challenges for water supply systems. By 2025, half of the world's population will be living in water-stressed areas.

Waste disposal habit of the people, work attitude, inadequate manpower or limited and incapacitated volunteer Waste pickers, plants, equipment for waste management workers and corruption on the part of both government officials and prosecutors, among others are militating against effective waste management to attain sustainable development in Nigeria as a whole. One of the challenges is that individuals and industries (most importantly) have no respect for the rules (or even established treaties) which have been ratified either at Federal or state levels. It has also been difficult to ensure that appropriate sanction should be imposed on erring organizations, industries, or individuals. In other words, there is no strict penalty in case of poor adherence or implementation of waste-related rules and regulations. Establishing a mobile court to try waste-related offenders have the tendency of limiting the damages. Imposition of user charge and fine will improve waste collection. Industries, should be made to present workable and realistic waste management mechanisms before being issued a license or permit to operate.

\section{References}

Adewole, A. Taiwo Waste management towards sustainable development in Nigeria: A case study of Lagos state.

Akpoghome, Theresa U. Managing Domestic Waste in Nigeria: Legal Framework, Problems and Solutions. International Journal of Environment, Ecology, Family and Urban Studies (IJEEFUS) ISSN(P): 2250-0065; ISSN(E): 2321-0109, Vol. 4, Issue 6, Dec 2014, 7-28

Bainbridge T. (2006). Secondary materials: Will new rules make a new beginning for the end-ofwaste? Conference proceedings of theWaste2006 conference held in Statford-upon-Avon, Warwickshire, U.K. 
Cap 131 Laws of the Federation of Nigeria, 1990 [formerly Decree No. 58, 1988] Cap. F10 LFN 2004 Food and Agricultural Organisation (FAO, 2007): Coping with water scarcity, 2007 World Water Day, 22nd March, 2007. Available on 1270172010 from: http://www.fao.org/nr/water7docs/wwd07bro chure.pdf.

Garba, Z. N., Leke, L., Almustapha, M. N., Adam, I. K. Domestic Water Pollution among Local Communities in Nigeria: Causes and Consequences.

Garba, Z.N., Hamza, S.A and Galadima, A. (2010) Arsenic level speciation in fresh water from

Karaye Local Government Area, Kano State, Nigeria. International Journal of Chemistry, India.

Vol. 20, No. 2: 113-117.

National Environmental (Sanitation and Waste Control) Regulations, 2009.

Ogwueleka, T. Ch., Municipal solid waste characteristics and management in Nigeria. Iran. J. Environ. Health. Sci. Eng., 2009, Vol. 6, No. 3, pp. 173-180 173

Oelofse, S.H.H., and Godfrey, L. Defining waste in South Africa: Moving beyond the age of 'waste'. South African Journal of Science 104, July/August 2008.

Regulations 3 (1) (2) (3), National Environmental (Sanitation and Waste Control) Regulations, 2009.

Section 1 (2) (a) NESREA Act, 2007.

Section 1 (2) (b) (c) NESREA Act, 2007.

Singapore Ministry of Environment (2002). Environmental Public Health Act, Act 14 of 1987; 2002 revised edition. Available online: http://statutes. agc.gov.sg

Staker C. (2005). The definition of 'waste' in the Waste Framework Directive. Eur. Curr. Law, March 2005.

TVC News Nigeria, Waste management, an environmental challenge in Nigeria, July 26, 2019.

Understanding the Basics of Waste management, https://skipthetip.com/understanding-basic-waste-ma nagement/.

Wale Adebiyi, Recycling in Nigeria by WeCyclers. Wazobia Max TV.

What is waste Management? Reduce Reuse Recycle. Environmental Science. Letsute. Published on March 4, 2019. https://youtu.be/K6ppCC3lboU.

World Health Organization, Drinking Water, 14 June 2019, https://www.who.int./news-room/fact-sheet s/detail/drinking-water.

World Health Organization, Drinking Water, 14 June 2019, https://www.who.int./news-room/fact sheets/detail/drinking-water.

United Nations, Water, Sanitation and Hygience, https://www.unwater.org/water-facts/water-sanitation -and-hygiene/.

1999 Constitution of the Federal Republic of Nigeria as amended. 